\title{
The Societal Benefits and Costs of School Dropout Recovery
}

\author{
James S. Catterall \\ Department of Education, University of California at Los Angeles, Los Angeles, CA 90024, USA \\ Correspondence should be addressed to James S. Catterall, jamesc@gseis.ucla.edu
}

Received 13 September 2010; Accepted 11 December 2010

Academic Editor: John C. K. Lee

Copyright $\odot 2011$ James S. Catterall. This is an open access article distributed under the Creative Commons Attribution License, which permits unrestricted use, distribution, and reproduction in any medium, provided the original work is properly cited.

\begin{abstract}
This article reports an analysis of the societal benefits and costs of recovering school dropouts. Successful recovery is defined by subsequent graduation from high school. The analysis is based on established estimates of the societal costs of dropping out including reduced government tax collections and higher social costs of welfare, healthcare, and crime. These potential costs are cast as benefits when a dropout is recovered. A large dropout recovery program provides the setting for the analysis. Rigorous attention is given to accurate estimation of the number of students who would not have graduated without the program in the year assessed and to the induced public costs of their continued education. Estimated benefits are weighed against the total annual public costs of the program, which operates in 65 school centers and commands an annual budget of about $\$ 70$ million. The estimated benefit-cost ratio for this program is 3 to 1 , a figure comparable to benefit-cost ratio estimates reported in studies of dropout prevention. The sensitivity of this conclusion to specific assumptions within the analysis is discussed.
\end{abstract}

\section{Overview}

This paper reports an analysis of the benefits and costs of recovering school dropouts. Dropout recovery refers to efforts that encourage adolescents who have left school without a diploma to re-engage in formal education and graduate from high school. This analysis focuses on societal benefits and costs. Individual benefits of completing high school include additional lifetime personal income, reduced reliance on various public services, and reduced costly behaviors such as crime. Society in turn stands to benefit from added tax revenues and decreased expenditures for public services.

The analysis assesses a specific program engaging a dropout recovery model based on supervised independent study. This program operates nine public charter schools in the United States that enrolled a total of more than 10,000 fulltime equivalent students in 2006-2007. Based on annual numbers of actual graduates, the benefit-cost ratio of dropout recovery through this program is estimated to be 3 to 1 . In other words, one dollar invested in this program should return $\$ 3.00$ in societal benefits. Our analysis tests the sensitivity of our estimates to key assumptions and projections underlying the calculations. We estimate that the program's benefit cost ratio lies between 2.7 and 3.4.

\section{Sizing Up the Problem}

By any indication, dropping out of school is a significant problem in American schools, one that has not responded significantly to public programs or policies over the past three decades. Levin and colleagues [1] reported that only 66 to 70 percent of public high school students currently manage to receive a diploma "on time," that is, alongside their original 9th grade classmates (p.3). Freudenberg and Ruglis [2] write that according to the US Bureau of the Census, "...nearly one-third of students in the United States and half of black, Hispanic, and American Indian students who enter 9th grade do not graduate with a diploma in 4 years." Bloom [3] reports national studies in the USA estimating that "...3.5 million to 6 million people between the age of sixteen and twenty-four are high school dropouts..." with no high school diploma and not enrolled in high school. These estimates and reports are consistent with the state graduation rates reported to average about 70 percent in the early 1980s by the United States Department of Education [4, 5].

Beyond national and state dropout statistics lie more discouraging stories from our largest cities. Take for example, the Los Angeles Unified School District, which borders 
most of the school districts served by the dropout recovery program assessed in this paper. In the Los Angeles schools, the on-time graduation rate is about 51 percent overall, and 40, 48, and 68 percent for Latino, black, and white students, respectively [6]. National dropout rates in urban school districts hover generally at about 40 percent [7]. Suffice it to say that dropping out affects large numbers of adolescents in the United States and the problem weighs disproportionately on disadvantaged minority students. Even if dropping out was only half the problem these statistics indicate, the human and societal costs would nonetheless prove staggering.

\section{The Costs of Dropping Out of School-or the Benefits of Finishing}

As Orfield [8] recently put it, life without a diploma is "financially disastrous." Orfield was referring to the $\$ 270,000$ lifetime earnings deficit reported in his recent book. An analysis in 1987 pegged the discounted present value of individual earnings to be gained by graduating as opposed to dropping out of school at about $\$ 265,000$ for males and $\$ 203,000$ for female students, with gains to society in added income tax collections of about $\$ 71,000$ per dropout on average [9].

A detailed analysis of what society stands to gain from dropout prevention was reported by Levin and colleagues in 2007 [1]. These authors argue that from a social perspective, graduating from high school generates not only increased lifetime earnings benefiting the students who manage to graduate, but also produces returns to the public trust in the form of additional tax revenues based on individual income streams. The authors reason that graduates benefiting from increased earnings also benefit society through reduced dependence on public services and lower participation in socially costly behaviors such as crime. Their analysis focuses on the present value of these benefits generated when students considered to be at high risk of dropping out instead stay in school to graduate. The analysis then estimates the benefits generated by several specific dropout prevention programs.

While reporting the details of Levin's benefits analysis is not our present intention, his conclusions about the benefits and costs of dropout prevention are worth noting and serve as key building blocks for the analysis offered here. The benefit-to-cost ratios of dropout prevention through five program models or reform scenarios assessed by Levin range from about 1.5 to 3.5. That is, a thousand dollars invested in dropout prevention would return somewhere between $\$ 1500$ and $\$ 3500$ in social benefits, depending on the program selected. These results support arguments for additional public investment in dropout prevention and provide some guidance about what approaches might generate the greatest payoff. These results also align with the findings of a comprehensive review of the benefits and costs of early interventions for youth reported by Aos et al. [10].

Our analysis builds on this study. We enlist its wellsupported estimates of the benefits of graduating as opposed to dropping out. Attaining these benefit estimates required
TABLe 1: Average societal (USA) benefits or cost reductions per student attributable to graduating versus not-graduating from high school, by benefit or cost domain (1).

\begin{tabular}{ll}
\hline Domain & Gain/saving \\
\hline $\begin{array}{l}\text { Extra lifetime tax payment contribution } \\
\text { Decreased dependence on public health } \\
\text { expenditures }\end{array}$ & $\$ 139,100$ \\
$\begin{array}{l}\text { Reduced criminal activity } \\
\text { Reduced dependence on welfare }\end{array}$ & $\$ 40,500$ \\
$\begin{array}{l}\text { Average total individual benefit from } \\
\text { preventing or recovering school dropouts: }\end{array}$ & $\$ 26,600$ \\
\hline
\end{tabular}

(1) Source: Levin et al. [1, Pages 9-17]. Levin reports these rounded subtotals, but a grand total of $\$ 209,100$ when summing nonrounded estimates.

careful reasoning from data and research in areas as diverse as population surveys, public health, welfare, and criminology. And we use these projections of the benefits of finishing high school to assess the benefits and costs of inducing graduation through a different approach. We focus our work on dropout recovery, rather than on dropout prevention. Recovery refers to re-enrolling and re-engaging students who have already dropped out; prevention refers to keeping would-have-been dropouts in school through graduation. We consider the positive benefits of a dropout recovered to be the same as the benefits of a dropout prevented.

Table 1 shows the key components of the benefits of finishing high school.

One is the lifetime total of extra tax payments of $\$ 139,100$ per dropout prevented or recovered. Other benefits shown include a savings of $\$ 40,500$ in public health expenditures, reduced criminal activity saving the public $\$ 26,600$, and reduced expenditures on public welfare amounting to $\$ 3,000$ per student induced to graduate through programmatic efforts. The average social return generated by producing a high school graduate is shown as $\$ 209,200$.

\section{A Note on Estimation Methods}

A general procedure underlies estimating these benefits, as do some key assumptions. The general method is to seek out data describing incomes, public service use, and criminal involvement by adult individuals with a high school diploma in comparison to adults without a diploma. For income estimates, the Bureau of the Census reports average annual incomes for adult individuals at all age levels, and by gender and ethnicity. Gross lifetime income differentials favoring high school graduates show up as the sum of the annual income differences from age 18 to 65 . Each annual income difference, starting at age 18 and ranging over more than 40 years of a work life, is discounted to present value according an assumed discount or "interest" rate. Such discounting is necessary to put alternative flows of benefits and costs on the same footing-namely, the discounted present value. Note that higher discount rates, other things being equal, would lead to lower present values; lower discount rates produce higher present values. Levin's 
estimates of future costs and benefits are discounted using a 3.5 percent discount rate, a common standard for such analyses. (We discuss the implications of this choice of discount rate below. A 3.5 percent rate was used in the analysis of the dropout prevention programs we discuss and thus anchors a comparison with this dropout recovery program. Cyclical movement in interest rates, for example, a US federal discount rate nearing 0 percent in late 2010 and nearing 20 percent in 1980, causes one to puzzle over what rate is best for a lifetime income stream. Our brief sensitivity analysis points to the effects of choosing lower or higher discount rates to achieve present values of benefit or cost streams.)

Available data about participation rates and benefits related to public services also show differences by education level and project benefit differences for high school graduates versus dropouts. The substantial difference in lifetime expenditures on public health services reported by Levin, $\$ 40,600$ more for dropouts, was calculated from a recent Department of Health and Human Services (2004) survey of Medicaid and Medicare recipients (public health program beneficiaries under age 65). Information on who benefits was combined with information about the costs of these programs to estimate differences between dropouts and graduates.

An important assumption underlying this work is that attaining a high school diploma, as opposed to dropping out of school, endows individuals with skills and attributes that contribute to productivity_-skills that are rewarded with higher incomes in the labor market both as higher wages and also in higher likelihood of being employed at any given time. Levin et al. [1] contend that existing studies support a consensus among labor economists that the differential monetary labor market rewards to high school graduates, in contrast to dropouts, reflect differences in what they learned in school (p.6). These differences may derive from both increased skills as well as increased motivation tied to developments such as gains in self-efficacy beliefs spawned in high school.

\section{The Options for Youth/Opportunities for Learning Dropout Recovery Programs}

With the prospects of such benefits in mind, we turn here to a sizeable dropout recovery program operating in the Los Angeles area to explore what it actually can cost to recover dropouts and to produce associated social gains. First we provide a description of the program and its students. We then examine the program's success in turning its former dropouts into high school graduates. Finally, we bring program costs into the analysis to compare society's investments in dropout recovery through OFY/OFL to the societal returns.

\section{Program Description}

The program in question is composed of nine California public charter schools that operate independent-study programs for school dropouts who wish to return to school and to progress toward the diploma-as well as for students sufficiently disaffected from prior schools to make a change. These schools function under one of two organizational umbrellas-Options for Youth, Inc. (OFY) based in Pasadena and Opportunities for Learning, Inc. (OFL) based in La Canada. These organizations evolved from a single independent study program founded in the Los Angeles Unified School district about 20 years ago. The schools operate under identical instructional and student policies, employ teachers with similar distributions of experience and backgrounds, and draw on the same curricular materials. The program operates out of more than 60 facilities across eight partner school districts. Most facilities are in large accessible storefronts furnished, equipped, and networked to accommodate the comings and goings of students and teachers. Host school districts include Burbank, San Gabriel, Upland, Victor Valley, and San Juan (five OFY California charter schools) and Baldwin Park, Wm. S. Hart/Santa Clarita, and San Juan Capistrano (four OFL California charter schools). For purposes of this analysis, we refer to these schools collectively as the OFY/OFL program.

Most students enter OFY/OFL charter schools between the ages of 15 and 17. Many are behind in school credits needed for graduation, at least when compared to nondropouts at the same age. A majority had dropped out of school before enrolling - a share estimated at about 75 percent by program administrators and teachers. When asked in periodic interviews across the OFY/OFL public charter schools, students frequently cite lack of progress toward graduation as their reason for having dropped out. Some note safety or gang issues as cause for leaving. A common problem identified by OFY/OFL students is their lack of meaningful contact with teachers or other adults at their former schools - and a resulting sense that no one at school understood their needs or cared much about them. Parents interviewed consistently echo these assessments. (Between 1996 and 2006, Research Data Services conducted more than 8000 interviews with students, parents, and teachers in OFY/OFL schools-a process that supports useful generalizations about where the students come from and why and how OFY/OFL works for them.) Some older OFY/OFL students had work schedules incompatible with the routines of regular high school; some OFY/OFL students left their prior schools as new or expecting mothers. Some students talk about the difficulties of studying five high school subjects at once. OFY/OFL schools cater to a heavily ethnic and disadvantaged population, especially African Americans, Hispanics, and other students from low-income families.

OFY/OFL charter schools require entering students to read at about the beginning 6th grade level. The students work with published independent study course materials aligned with the California state academic standards. Students are assigned a teacher-like a case worker-who meets with them twice weekly throughout their enrollment at OFY/OFL to check on school work, administer tests, and outline upcoming assignments. These teachers are credentialed and many are designated as highly qualified under the No Child Left Behind Act provisions. Small group instruction and tutoring are offered at program centers. 
TABLE 2: Students who left OFY/OFL Charter Schools in 2006-2007, by destination and number of high school credits earned while enrolled in OFY/OFL.

\begin{tabular}{lccc}
\hline Student status & N total & $\begin{array}{c}\text { Mean credits at } \\
\text { enrollment }\end{array}$ & $\begin{array}{c}\text { Mean credits } \\
\text { earned }\end{array}$ \\
\hline Graduated & 1304 & 93.8 & 104.6 \\
& & $69.7(2)$ & 63.9 \\
Returned to school & & 0.0 & 21.1 \\
$\quad$ Entered with no credits & 4367 & & 31.6 \\
$\quad$ & & 70.0 & 34.6 \\
$\quad$ Entered with credits & 3336 & 49.0 & 33.2 \\
$\quad$ & & & \\
$\quad$ Subtotal ret. to sch. & 7703 & 34.4 & 33.3 \\
Dropouts & 3196 & 52.4 & 37.6 \\
& & & \\
Other leavers (1) & 1260 & & \\
Total leavers & 13463 & & \\
\hline
\end{tabular}

(1) Includes illness, child-bearing, overage, expulsion, moved out of country, and other reasons.

(2) Standard deviation.

Students must succeed in meeting state requirements for graduation, including course-completion requirements and passing the California High School Exit Exam. OFY/OFL schools serve their students effectively by state assessment standards. They are reported to perform in the top one, two, or three deciles among public schools serving "similar" populations, and their language arts and mathematics scores surpass those of model continuation schools identified by the state.

\section{The Benefits of the OFY/OFL Program}

There are various ways that the benefits of the OFY/OFL programs might be conceived and measured. Annual program evaluations have attended to achievement indicators such as student test scores, assessments of student writing, systematic appraisals of program elements by students, parents, and teachers, and investigations of what students do when they leave OFY/OFL. (Annual independent program evaluations of Options for Youth and Opportunities for Learning Public Charter Schools are available dating back to the initial operating years of each charter school involved.) It is this last measure that interests us for the present analysis. The goal of dropout recovery is bringing students back into a situation where they can succeed in obtaining a high school diploma. Based on what we presented above concerning the societal benefits of graduating, it is possible to gauge the achievements of the OFY/OFL program through its shepherding of former dropouts to graduation.

What can we say about OFY/OFL's performance on this score? The program documents the destinations of students who leave the program-sufficiently to provide important insights about returns to investments in the program. Table 2 shows critical information from the program database. In
2006-2007, more than 13,000 students left OFY/OFL charter schools for one reason or another. Consistent with past years, about 10 percent of students who leave in a given academic year do so through graduation. Another 57 percent leave OFY/OFL to return to a regular public school. And about 24 percent leave apparently as dropouts once again. Another 9 percent leave for a variety of other reasons: illness, being over-age, expulsion, childbirth or child rearing, incarceration, and so on.

When it comes to making graduates out of dropouts, two of the statistics cited above are most important. The OFY/OFL programs graduated 1304 students in 2006-2007. These are unambiguous successes for the students involved. As an accurate estimate of dropouts recovered by these schools, this estimate of successful program graduates must be adjusted to reflect only students who would not otherwise have been expected to graduate in the absence of the program. In addition, the 7,703 students who left to return to regular schools represent potential successes: their "recovery" through the OFY/OFL program may, for some of these students, lead in turn to graduation from their subsequent schools. Estimating graduates from this group attributable to the OFY/OFL program is another critical step.

If we are to assess OFY/OFL according to its record in producing high school graduations that would not otherwise have occurred, these numbers provide a basis for this accounting. The analysis begins in Table 2 on the following page. First we identify the 1304 actual program graduates. We also show information about the graduates that helps distinguish their program experiences from those of other students. The successful graduates initially enrolled at OFY/OFL with about 94 high school credits on average, out of 230 credits required for the high school diploma in California.

Students also leave the OFY/OFL programs without graduating, but with prospects of graduating in the future. A total of 7,703 students left the OFY/OFL programs in order to return to a regular school. These students should be counted as successes at one level-returning youth to school puts them on track to graduate; and from the point of view of the school districts housing the OFY/OFL charter schools, the additional enrollment and pupil-based revenues are beneficial. One large group of school returnees is the 3336 students who had entered with some high school credits in their records, an average of 70 credits at entry. Another 4367 return-to-school students had entered OFY/OFL programs with no credits toward high school graduation on their records.

We do not have concrete data about the ultimate fortunes of OFY/OFL students who return to regular schools. It is safe to say that some of these students will receive diplomas based on additional schooling after leaving OFY/OFL. We do know that when these two groups left to return to schools, those who had enrolled at OFY/OFL with some credits left with an average of about 135 credits. Those who had enrolled with no credits left with an average of 21 credits. On average, the first group left with late 10th grade status based on their credits. The second group left, on average, with less than a semester of high school under their belts. 
TABLE 3: OFY/OFL graduates in 2006-2007.

\begin{tabular}{lcccc}
\hline Student status & $N$ & Graduation rate & $\begin{array}{c}\text { Percent attributed } \\
\text { to OFY/OFL }\end{array}$ & $\begin{array}{c}\text { Graduates credited to } \\
\text { OFY/OFL }\end{array}$ \\
\hline $\begin{array}{l}\text { Students graduated } \\
\text { Students returned to school by entry credit }\end{array}$ & 1304 & $100 \%$ & $59 \%$ & 769 \\
status & & & & \\
$\quad$ Entered with no credits & 4367 & $5 \%$ & $59 \%$ & 129 \\
$\quad$ Entered with credits & 3336 & $5 \%$ & $59 \%$ & 98 \\
Totals & 7703 & & & $\mathbf{9 9 6}$ \\
& & & & Recovered dropouts \\
\hline
\end{tabular}

Table 3 displays the estimates we used to project the numbers of actual and projected graduates whose success in attaining the diploma should be attributed to participation in OFY.OFL. A survey of pending graduates in spring 2008 suggests that 59 percent of graduates would not have finished high school in the absence of the opportunity presented by OFY/OFL. Forty one percent of the students surveyed claim they probably or surely would have graduated anyway. This suggests that 769 actual program graduates succeeded in OFY/OFL after dropping out of school because of the program. We also project, in an effort to be conservative, that 5 percent of students who left OFY/OFL to return to high school will ultimately graduate and that 59 percent of this group would graduate because of the program. These estimates lead to a projected total of 996 dropouts successfully "recovered" by the OFY/OFL program, as shown in Table 3. We proceed with cost and benefit calculations using this total as the annual success count for OFY/OFL. We also test the sensitivity of our assessment to the accuracy of these projections.

\section{What Are the Costs of Recovering These Dropouts?}

As charter schools, the OFY/OFL programs are responsible for essentially all fixed and variable costs of maintaining and operating their entire programs. They lease their own school facilities and office space; they purchase, warehouse, and distribute their own curriculum materials; they hire credentialed teachers in an open market and establish employee compensation and benefits; they participate in few if any state or Federal categorical programs. As a result, the total cost of operating what amounts to a largescale dropout recovery program is the per-pupil subvention allocated to OFY/OFL charter schools by the state of California.

Per-pupil support levels for the OFY/OFL programs are based on the per-pupil revenue limits, or state per-pupil general funding, of the school districts hosting the charter schools. For 2006-2007, general fund expenditures averaged about $\$ 7,500$ per pupil across the state. In the eight school districts hosting the nine OFY/OFL charter schools, the perpupil spending figure is similar: $\$ 7,476$. Independent study charter schools are treated as a special class of schools for funding determination. Independent study charter schools are allocated a significant percentage but not typically all of the host school district's per-pupil state grant or "revenue limit." The total full-time equivalent enrollment in these schools for the same year was 10,980 . The total operating budget of $\$ 58.8$ million is shown in the first line of Table 4.

As we outline further in Table 4, we include three components in our estimate of the costs of attaining dropout recoveries in these programs. One is the $\$ 58.8$ million cost of operating the program in the first place. The second is the cost of the additional education the returnto-school students would incur in the process of earning their diplomas. And the third is the public costs incurred when students propelled to graduate go on to public higher education.

We show our calculation of these costs in Table 4. The 98 returning-to-school (eventual) graduates who originally enrolled at OFY/OFL with no high school credits have a long way to go before graduating. Based on their accumulated credits when leaving OFY/OFL, they need about 3.7 full years of high school on average. The 129 returning-to-school graduates who had originally enrolled at OFY/OFL with some high school credits need on average a little more than two full school years in order to graduate. Using the host school districts' per pupil costs of $\$ 7476$ per year, the total expenditure needed for this number of students we observe or project to finish high school amounts to about $\$ 10.2$ million.

We also include an estimate of the costs of continuations into public postsecondary education for the graduates "produced" by OFY/OFL. We engage assumptions argued by Levin about the postsecondary destinations in this population. A majority are likely to try two-year colleges for a semester, a quarter, or less. About one student in six will attain two-year community college certificates, and about eight percent will attain four-year college degrees. We used public cost estimates in California colleges to calculate a weighted average per student postsecondary education [11]. The estimated costs of postsecondary education for the graduates of OFY/OFL in 2006-2007 come to about $\$ 6$ million. And the total cost of "recovering" these 996 students reaches about $\$ 70$ million—or about $\$ 70,000$ per recovered dropout. 
TABLE 4: Costs of OFY/OFL Dropout recovery, 2006-2007; Total and average costs Per HS graduate.

\begin{tabular}{|c|c|c|c|c|c|c|}
\hline \multicolumn{6}{|c|}{ Total program expenditures, 2006-2007 } & $\$ 58,800,000$ \\
\hline \multicolumn{7}{|c|}{ Induced costs of educating students who return to public schools to graduate: } \\
\hline Student status & $\begin{array}{l}\text { Projected } N \text { of } \\
\text { induced } \\
\text { graduates }\end{array}$ & & & & $\begin{array}{l}\text { Induced cost of } \\
\text { postsecondary } \\
\text { education (1) }\end{array}$ & \\
\hline Graduated & 769 & & & & $\$ 4,614,000$ & \\
\hline Returned to school & & $\begin{array}{l}N \text { years from } \\
\text { recovery to } \\
\text { graduation }\end{array}$ & $\begin{array}{l}\text { Induced cost of } \\
\text { finishing high } \\
\text { school per } \\
\text { student }\end{array}$ & $\begin{array}{l}\text { Total cost of high } \\
\text { school } \\
\text { completion after } \\
\text { return to school }\end{array}$ & & \\
\hline Entered with no credits & 129 & 3.7 & $\$ 27,661$ & $\$ 3,568,295$ & $\$ 774,000$ & \\
\hline Entered with credits & 98 & 2.3 & $\$ 17,195$ & $\$ 1,685,090$ & $\$ 588,000$ & \\
\hline Sub-total ret. To Sch. & 227 & & & $\$ 5,253,385$ & $\$ 5,976,000$ & $\$ 11,229,385$ \\
\hline Total graduates & 996 & & & & & \\
\hline \multicolumn{6}{|c|}{ Total costs of recovery of 996 dropouts } & $\$ 70,029,385$ \\
\hline \multicolumn{6}{|c|}{ Average cost per graduate: (I.E. per recovered dropout) } & $\$ 70,311$ \\
\hline
\end{tabular}

TABLE 5: Ratio of benefits to costs of OFY/OFL dropout recovery.

(A) Annual social benefits associated with OFY/OFL Recovered dropouts, 2006-2007

(a) Total graduates (recovered dropouts) per Table 3

(b) Net present value of societal benefits per graduate (per Table 1)

(c) Present value total societal benefits $(\mathrm{a} \times \mathrm{b})$

(B) Net social benefits and benefit cost ratio

(d) Net present value of total costs, per Table 4

(e) Present value NET total benefits (c-d)

$\$ 138,333,815$

(f) Benefit Cost Ratio, current dollars (c/d)

3.0

\section{The Social Benefits of OFY/OFL Dropout Recovery}

We showed in Table 3 that the OFY/OFL programs produced 769 graduates from among former school dropouts in 20062007 , and we conservatively projected that out of the 7,703 former dropouts who left OFY/OFL to return to regular school that year, 227 would eventually graduate because of the program. The calculations shown below in Table 5 extend these figures into the language of benefit cost analysis. In section A of this table, total societal benefits are calculated as total graduates multiplied by the present value of societal benefits per graduate, generating an estimate of about $\$ 208$ million. We then subtract the total costs of producing these dropout recoveries, shown above in Table 4, from the total benefits; this produces an estimate of the net social benefits associated with OFY/OFL dropout recovery for 2006-2007the $\$ 139$ million shown in line (e) of Table 5. Dividing total social benefits by total program costs yields a benefit cost ratio for the OFY/OFL schools of 3.0. This implies that onedollar invested in the OFY/OFL program will produce social benefits amounting to three dollars.

\section{Sensitivity Analyses}

What considerations can help shape our appraisals of and confidence in this benefit cost ratio? Are there characteristics of this analysis that challenge its validity? Are there aspects of the estimation process that might lead to overstatements or understatements of the effectiveness of the program? What would reasonable changes in any key parameters bring to the bottom line?

Table 6 shows the effects of three potential critical changes in the analysis on the projected cost benefit ratios.

We begin with the estimated ratio-3.0. If we increase our projections of the percent of students ultimately graduating from among the more than 7000 students who left OFY/OFL to return to high school from 5 percent to 7.5 percent, the estimated benefit cost ratio would increase to 3.4. Reducing our projections of graduates from among this group by half, or to 2.5 percent, would reduce the estimated benefit cost ratio to about 2.6. We also show the projected decrease in the benefit cost ratios under a reduced estimate of the benefits of graduating. This contingency allows for the possibility that the labor market benefits of 
TABLE 6: Sensitivity analyses benefit cost ratios under alternative assumptions.

\begin{tabular}{lc}
\hline & benefit cost ratio \\
\hline $\begin{array}{l}\text { As estimated: } \\
\text { Increase projected graduation rate for } \\
\text { students returned to school from } 5 \% \text { to }\end{array}$ & 3 \\
$7.5 \%$ & 3.4 \\
$\begin{array}{l}\text { Decrease benefits to graduating by } 10 \%: \\
\text { Increase discount rate from } 3.5 \%:\end{array}$ & 2.7 \\
Decrease discount rate from $3.5 \%:$ & reduces $B / C$ \\
\hline
\end{tabular}

TABlE 7: Benefit-cost ratios of alternative dropout prevention programs.

\begin{tabular}{lcc}
\hline Program & Cost per success & $\begin{array}{c}\text { Benefit-cost } \\
\text { ratio }\end{array}$ \\
\hline First things first & $\$ 59,100$ & 3.54 \\
Chicago parent-child center & $\$ 67,700$ & 3.09 \\
Teacher salary increase & $\$ 82,000$ & 2.55 \\
Perry pre-school & $\$ 90,700$ & 2.31 \\
Class size reduction & $\$ 143,600$ & 1.46 \\
Estimates per Levin et al. [1] & & \\
\hline OFY/OFL charter schools & $\$ 70,311$ & 3.0 \\
(Dropout Recovery) & & \\
\hline
\end{tabular}

an OFY/OFL diploma could be less than the labor market benefits conferred by a regular high school diploma for the same group of students. A ten percent decrease in the estimated benefits of graduating as opposed to dropping out of high school would reduce the benefit cost ratio to 2.7. We also remind ourselves and readers that increasing or decreasing the underlying discount rate used to convert streams of benefits and costs to present value would have the effect of reducing or increasing the estimated benefit cost ratios by unspecified amounts, respectively. The discount rate impacts most those benefits or costs that occur farthest into the future-mostly the benefits in this analysis because future income and tax collections are 40-year propositions and the costs of education are very near-term in comparison.

We consider our estimated benefit cost ratio of 3.0 to 1 for the OFY/OFL program to be robust-in addition, it implies a healthy positive return. We would say the same for estimates in the 2.7 to 3.4 range calculated in our sensitivity tests. Any of these estimates suggest that investments in the OFY/OFL schools are well leveraged and advantageous from the sponsoring society's point of view.

\section{Results in Context: Recovery versus Prevention?}

A useful point of reference for an appraisal of our analysis of the benefits and costs of dropout recovery under OFY/OFL is the benefits and costs of dropout prevention. Levin compared five alternative programs that could increase graduation rates among at-risk youth. These designs included preschool programs, a comprehensive school reform initiative, a general reduction of class size in grades $\mathrm{K}-3$, and a 10 percent across the board teacher salary increase in grades K-12. Some of these "programs" are targeted dropout prevention strategies-some are more general educational improvement strategies that could serve in part to keep students in school.

These comparison programs work to reduce dropout behavior in diverse ways. The Perry Pre-School project followed at-risk children who had attended an average of nearly 2 years of center-based preschool. The Perry followups persisted well into adulthood. First Things First was a school improvement reform initiative that created small learning communities with committed teachers, instructional improvements, and family advocates. Class size reduction as a dropout prevention program was based on reducing class size from 25 to 15 children in grades K-3. And increasing teacher salaries to reduce dropping out involved a policy that would increase teacher salaries by 10 percent throughout grades kindergarten through twelve.

Using research-based information, Levin projects as many as 19 extra graduates from among 100 students involved in one project (the Perry Preschool program) and as few as 5 extra graduates out of 100 dropout-likely students resulting from a teacher salary increase. The modal range of effectiveness across these five programs is a success rate of 11-16 percent of participating target students-above the 9.1 percent success rate our data imply for OFY/OFL. (996 graduation successes among 10,980 full-time equivalent students yields 9.1 percent.) Table 7 presents a summary of the costs per success of these programs as well as their benefit-cost projections. Included in Table 7 is the cost per success figures and estimated benefit-cost ratio for the OFY/OFL charter schools.

Levin et al. [1] calculate the costs per success across the five programs to range from $\$ 59,100$ (Perry Preschool) to $\$ 143,600$ (class size reduction). Thus the OFY/OFL schools are mid-range in terms of costs per averted or recovered dropout. The five dropout prevention programs show benefit cost ratios ranging from 1.46 to 3.54 . The benefit cost ratio for OFY/OFL programs is shown to be 3.0. This estimate fits reasonably in the range of benefit cost ratios reported for the five dropout prevention programs.

\section{Additional Contingencies/limitations}

Assumptions or projections we built into this analysis could affect our conclusions about the benefits and costs of dropout recovery through OFY/OFL. We tested the key assumption regarding the ultimate graduation status of students returned to school by OFY/OFL. We also built into our model an adjustment for the fact that some OFY/OFL graduates would have graduated anyway through some alternative path. Additional contingencies bear on these assessments. Included are conditions in the labor market or price levels differing from those used in the original estimation of benefits. Altered price levels might impact the cost of mounting prevention and recovery programs. Advancing costs of health care would 
imply added benefits of graduating; higher or lower levels of participation in welfare or involvement in crime by school dropouts would affect our conclusions. And as we noted, alternative valuing of future streams of income or costs would impact the present value of costs and benefits.

\section{Benefits Not Counted}

For this analysis, we focused solely on inducing high school graduation from among the 10,900 individual students enrolled at OFY/OFL in a given year. About nine percent of the student population in 2006-2007 found such success. Many of the remaining students would have gained something from the program beyond what we measured. Among these, about 7500 students returned to regular schools, students we did not project to graduate or contribute to the graduation-related benefits of the program. These students earned an average of 21 high school credits while at OFY/OFL. Most of these students would have made some progress toward finishing high school by returning to high school, a benefit we have not translated to dollars. That they all returned to regular schools suggests they are likely to continue pursuing the diploma.

\section{When All Is Said}

Concern about failure to complete school runs high in the USA; it is unrelenting and unrewarded, some would say. The main school-completion strategy showing in public policy is preventing students from dropping out in the first place through targeted interventions as well as through general efforts to make schools more effective and engaging. Very little has been reported about recovering the millions of students who have already dropped out. We know that both dropouts and society will benefit if dropouts subsequently find ways to earn high school diplomas. We need analyses that explore dropout recovery. Through what designs can this succeed? How can effective programs be replicated? And what resources are needed?

We conclude that under any reasonable projections, the social benefit-cost ratio of dropout recovery through the OFY/OFL model indicates a significant return to society. Our analysis built on reliable estimates of program costs, documented program graduation numbers, and a wellvetted estimate of the social benefits of graduating as opposed to dropping out. Our sensitivity analyses show that contingencies might affect the returns of the program measurably but not enough to overturn a positive conclusion. Our work suggests that there is "room" for exploration and experimentation with dropout recovery on the cost side; that is, benefits exceeding the costs of recovering dropouts may be realized through a variety of program designs. The return to social investment in dropout recovery through OFY/OFL certainly seems well worth the public's effort.

\section{Acknowledgment}

The author would like to thank the three anonymous reviewers for their helpful comments and suggestions.

\section{References}

[1] H. Levin, C. Belfield, P. Muennig, and C. Rouse, The Costs and Benefits of and Excellent Education for All of America's Children, Teachers College, Columbia University, New York, NY, USA, 2007.

[2] N. Freudenberg and J. Ruglis, "Reframing school dropout as a public health issue," Preventing Chronic Disease, vol. 4, no. 4, p. A107, 2007.

[3] D. Bloom, "Programs and policies to assist high school dropouts in the transition to adulthood," Future of Children, vol. 20, no. 1, pp. 89-108, 2010.

[4] USDoE, Wall Chart of Education Statistics, United States Department of Education, Center for Education Statistics, Washington, DC, USA, 1983.

[5] USDoE, Wall Chart of Education Statistics, United States Department of Education, Center for Education Statistics, Washington, DC, USA, 1984.

[6] G. Orfield, Ed., Dropouts in America: Confronting the Graduation Crisis, Harvard Education Press, Cambridge, Mass, USA, 2004.

[7] R. Weingarten, "Supporting at-risk high school students," The American Teacher, vol. 94, no. 5, p. 1, 2010.

[8] G. Orfield, In Maureen Magee, School Fight for Diplomas vs. Dropouts, San Diego Union, 2005.

[9] J. S. Catterall, "On the social costs of dropping out of school," The High School Journal, vol. 71, no. 1, pp. 19-30, 1987.

[10] S. Aos, R. Leib, J. Mayfield, M. Miller, and A. Pennucci, Benefits and Costs of Prevention and Early Intervention Programs for Youth, Washington State Institute for Public Policy, Olympia, Wash, USA, 2004.

[11] D. E. Heller, "Public subsidies for higher education in California: an exploratory analysis of who pays and who benefits," Educational Policy, vol. 19, no. 2, pp. 349-370, 2005. 


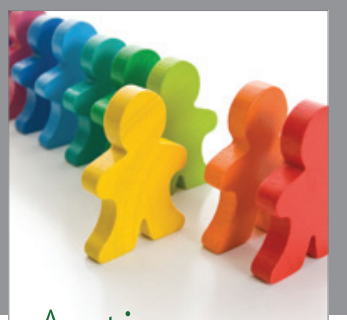

Autism

Research and Treatment
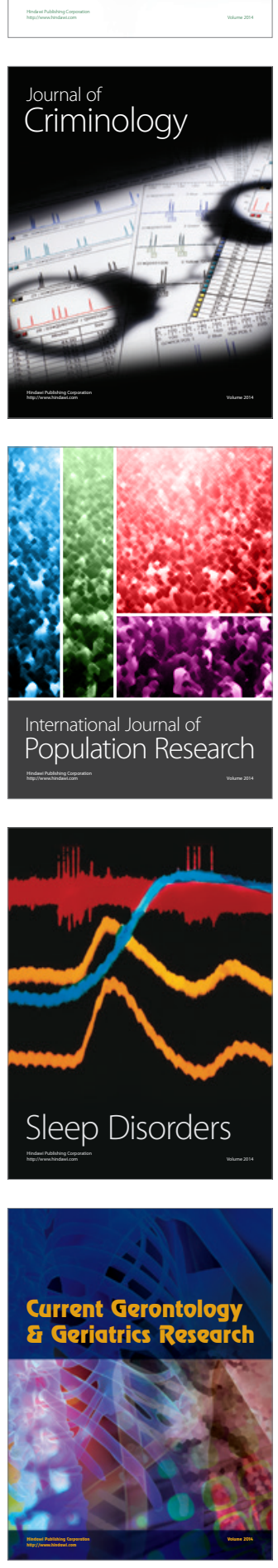
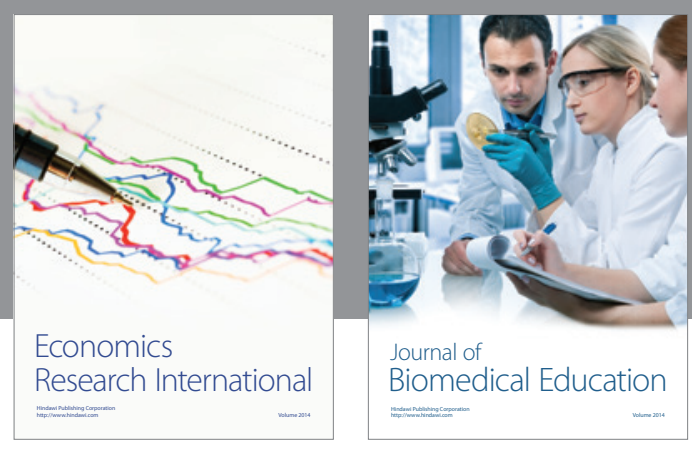

Journal of

Biomedical Education

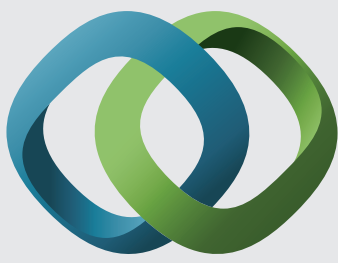

\section{Hindawi}

Submit your manuscripts at

http://www.hindawi.com
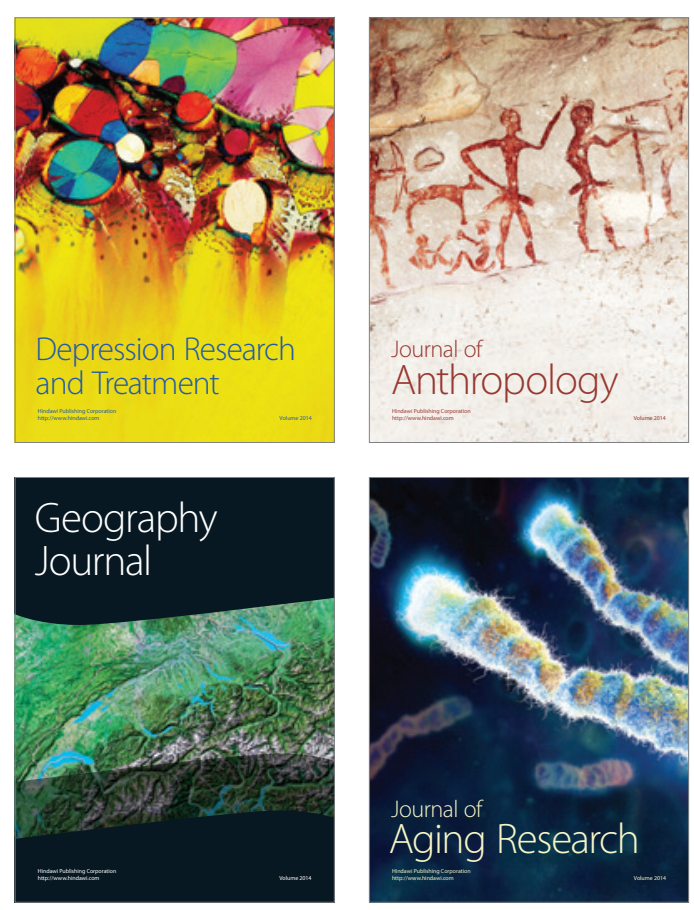

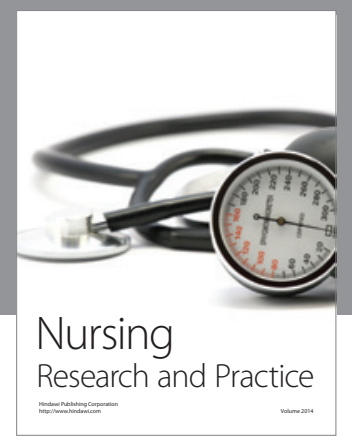

Nursing

Research and Practice

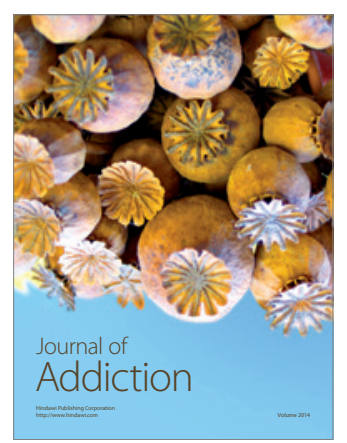

Child Development

Research

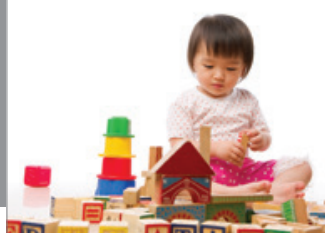

迥
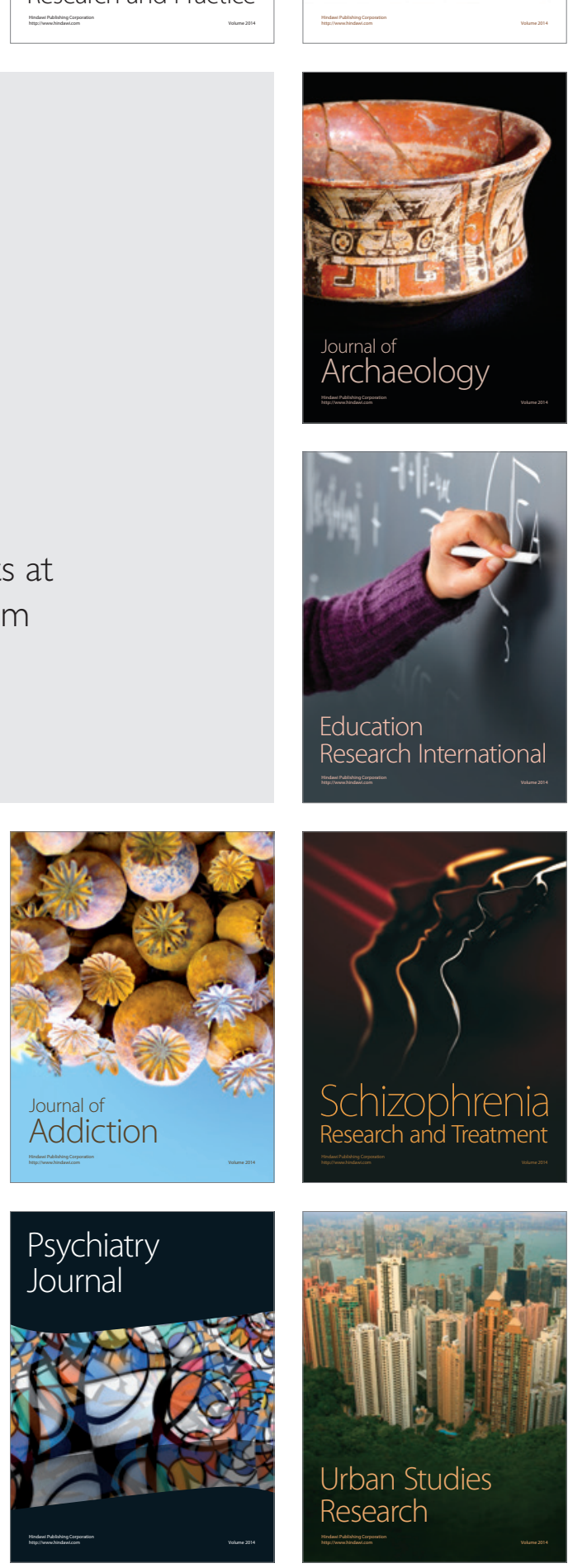